\title{
Semiotic Analysis: Social Critics Towards Government Depicted in the Songs of Marjinal Band
}

\author{
Lambok Hermanto Sihombing ${ }^{1}$, Aldy Marcelino Letwory ${ }^{2}$, Fedra Shopia Floriana ${ }^{3}$ \\ Department of Communication, President University, West Java, Indonesia \\ Email: lambok.president@gmail.com
}

\begin{abstract}
This research aimed to determine the meaning of the songs belonged to Marjinal band, a punk band whose songs contain critics to the government. The songs that the reasearchers analyzed were Hukum Rimba and Buruh Tani. The researchers used the data taken from various digital platforms and analyzed the lyrics using Semiotic Theory from Ferdinand De Saussure. Furthermore, the results of the research from Hukum Rimba and Buruh Tani song implied that people who had money and power would be spared by the law. Meanwhile, the poor would always be oppressed by the law.
\end{abstract}

Keywords: critics, government, lyrics, money, power

\begin{abstract}
Abstrak: Penelitian ini bertujuan untuk mengetahui makna lagu-lagu karya band Marjinal, sebuah band punk yang lagu-lagunya mengandung kritik terhadap pemerintah. Lagu-lagu yang peneliti analisis berjudul "Hukum Rimba" dan "Buruh Tani". Peneliti menggunakan data yang diambil dari berbagai platform digital dan menganalisis lirik menggunakan Teori Semiotik dari Ferdinand De Saussure. Hasil penelitian dari lagu "Hukum Rimba" dan "Buruh Tani" menginterpretasikan bahwa orang yang memiliki uang dan kekuasaan akan terhindar dari hukum; sedangkan, orang miskin akan selalu tertindas oleh hukum.
\end{abstract}

Kata kunci: kritik, pemerintah, lirik, uang, kekuasaan

Article info:

Received: 11 Juni 2021

Reviewed: 23 Juni 2021

Accepted: 29 Juni 2021

\section{INTRODUCTION}

Punk is a movement in social and cultural that demonstrates its expressions by mainstream media and music. The punk movement is often viewed as a youth culture based on teen adolescence angst. However, punk as a subculture goes much further than rebellion and fashion as punks generally seek an alternative lifestyle divergent from the norms of society (Moran, 2010).

According to Setyanto, D. W. (2015), in the 1990s, along with the advancement of technology, the existence of the Punk community began to grab the media attention and became popular. Moran (2010) stated that the development of punk tries to clarify its existence in society as a lifestyle adopted by a group of people which turns it into a subculture. According to Wallach (2008), he stated that the Punk exposure in the mid-1990s, the production and distribution of Punk music and ideology were dedicated to networks of bands, small independent record labels, until merchandisers. especially in Indonesia cities like Jakarta, Bandung, and Denpasar, by hyped group bands such as Green Day, Rancid, and The Offspring (Wallach, 2008). In Indonesia, punk music that had formed in Jakarta and commonly they protested songs against practices of different governments. For the particular reason for circumstance of the extreme government system that impoverishes citizens and the contempt of the people for the government, punk is rising relatively quickly in Indonesia especially at the time of reform, for this reason Indonesia is believed to be the largest community in the world today (Gumilang, 2017).

Punk irreverence manifests itself in many ways. Musically, punks adopt vocal styles that can sound like angry protests or sneering insults. Punks 
also make frequent use of obscene language; The Sex Pistols' John Lydon and Siouxsie Sioux, frontwoman of the Banshees shocked audience by swearing on television. Irreverence is also pervasive in the thematic content of lyrics. Some songs attack the prevailing political order. Punk is associated with anarchy, though the brand of anarchy presented usually has more to do with chaos and anti-authoritarianism, than with any specific political philosophy; thus, we find the Sex Pistols' "Anarchy in the UK" proclaiming, "I am an anarchist/don't know what I want, but I know how to get it/I want to destroy the passerby." Some bands, like Crass, were more politically astute about anarchism (Prinz, 2014).

Talking about punk music, most of people think that punk is one of the most violent music. However, beside the harsh tones, there is a deep meaning in every piece of the lyrics. According to Hornby (2000), he stated that the lyrics is expressing a person's personal feeling and thoughts, connected with singing and written for a lyric poem is the words of a song. Usually, this punk genre song is made to convey a message, message or even criticism to government officials. The lyrics of punk songs are also usually very representative of the state of society at that time, and that makes many punk songs liked by the community. More generally, punk rock often takes aim at political correctness. The Sex Pistols wrote a song about a postcard from a concentration camp and another apposing abortion. The Stooges, and later Sid Vicious, wore swastikas. These efforts were generally intended to shock, not to proselytize. Shock is not always linked to irreverence (consider a shocking love confession), but punk uses it to this effect, targeting entrenched standards of political acceptability. Consider some band names: The Dead Kennedys, The Rapists, The Wife Beaters, The Child Molesters, The Cripples, and female fronted groups called Penetration, The Dishrags, and The Slits (Prinz, 2014).

Punk is an assault on prevailing canons of beauty. Punk songs are often out of tune, off key, incompetently played, and poorly recorded. Punk fashion can be shabby (a tattered shirt) or grotesque (a safety pin in the cheek). Punk is a celebration of ugliness and discord. Punk rockers regard these features as good precisely because others regard them as bad. But how can norms be inverted? There is a long-standing tradition that seeks to identify universal aesthetic norms, based in human nature and amenable to objective characterization (Hutcheson 1994; Ramachandran and Hirstein 1999).

Generally, punk music is known for its sarcastic and frontal lyrics and song meanings. However, behind the sarcastic lyrics there is a very deep meaning to the song. Many of the street punk musicians make songs based on current conditions. Some of them expressed their frustration with the government's performance through the songs they composed. Marginal Band for example. Marjinal band itself is an underground punk music group from the many indie groups in Indonesia. This group always makes music or songs that contain criticism or messages about the suffering of the community. Many of their songs are known for their lyrics that sound offensive to the government, such as; "Buruh Tani", "Indonesia Memanggil", "Marsinah", "Koruptor", and many more. Many of their songs are used as an anthem when people are doing demos or orations, because the lyrics of the songs really describe the situation that is happening in the society.

The group consists of 4 members, namely Romi Jahat (vocalist), Mike (guitar), Bob (bass) and Steven (drum). Members of this music group are also aggressively looking for income, through musical performances, selling handicrafts, posters, making tattoos, and making bracelets from leftover food wrappers. However, the harshness of their lives does not close the steps to help small communities who are often marginalized, one of which is by helping the empowerment of coffee farmers who are suffocating at uncommon selling prices. The stretching and persistence of their actions is like seeing their lyrics become real action. Believing everyone has a Punk side in themselves, Marjinal may not stop to dare to shout out the anxiety that is felt by society.

One of Marjinal band's songs is entitled "Hukum Rimba", this song is one of the songs that contains criticism on their album. This song was released on January 21, 2016. "Hukum Rimba" is intended to insult government officials who make Indonesian laws to uphold justice but in fact the law itself is not fair. Where petty crimes committed by the poor are subject to very severe laws, while officials who commit major corruption are only given light punishments. The message is implied in his chorus "Small thieves are judged ... Big thieves are protected ...". This song is very popular among street musicians such as buskers, laborers and demonstrators. The lyrics, which are very relevant to 
the current state of Indonesia, have earned this song a place in the hearts of the people.

However, based on the research, not many have downloaded these songs, but many also appreciate them. For example, during a demonstration in 2019 when students and students took to the streets demanding the annulment of the KPK Law at that time. The students sang the jungle law song simultaneously, because it was felt that the song really represented the state of Indonesia at that time. And also during the early October 2020 demonstration yesterday. The moment when students represent workers' voices to reject the ratification of the omnibus law which will torment the fate of the workers, and again the song "Hukum Rimba" from Marjinal is played to arouse the enthusiasm of the demonstrators in expressing their opinions.

Punk in Indonesia is seen by the general public as a marginalized culture. The marginalization that was carried out by the community did not necessarily make the punks know all levels of society. Punk is well aware that they are also a part of society that is underestimated. The little people are the groups of people who serve this way. Therefore, they position themselves as defenders of the little people who are always victims of power. Marginalized, as part of the small people position themselves as defenders of the people.

From the lyrics the song "Hukum Rimba" focused on the injustice of exercising control of the law by those in power. Swear propaganda techniques are also included in the lyrics of the song "Hukum Rimba". In the lyrics of this song, they give a guarantee that the law does not stand for justice. The law only benefits those with money and permits. Small criminals who get unfair treatment are different from big criminals. From vigorous surgery, treatment shows that their weak data will always suffer and will always be the ruler. The oath technique in the lyrics of the song "Hukum Rimba" can be seen clearly from the lyrics read,It is clearly stated in the quote that the law can be bought with money and the law can be used as a tool to perpetuate power as long as we have money. Propaganda techniques condemn this lyrical quote against law enforcement agencies including supervisors, juries, judges and prosecutors. Each of these legal instruments has a role in determining whether a person is right or not. In this last stanza, the application of distrust to legal institutions in this land. This distrust occurs because the laws in this country still belong to the rulers. Where there is justice, if you see "kuat selalu berkuasa yang lemah pasti merana". The phrase "kuat selalu berkuasa yang lemah pasti merana" in the lyrics shows the helplessness of the little people who are always oppressed by the authorities. They want to state that the laws of this country are like the laws of the jungle. This is the point of always being the won and the beneficiary and the weak always being an unfair use. In fact, it is enough to see the analogy of the law of the jungle as the law in this country, the swearing technique in the lyrics can already be seen. In this study, the researchers analyzed how social criticism depicted in the songs of Hukum Rimba and Buruh Tani.

\section{METHOD}

Semiotics Theory from Ferdinand De Saussure was used in this study. Saussure (Budiman, 2011) conceptualizes semiotics with a linguistic approach. In this case, linguistics deals with logical relationships and psychological relationships which then create a system in shared thinking. Lingustics was then categorized by Saussure into two types of analysis, namely synchronous investigation and diachronic investigation. Synchronous review is a review that explores a certain moment or it can be called now or it can be in today's popular language, called 'the present', where this present is obtained by putting aside the journey it has taken. On the other hand, reviews about diachronics are related to changes that take a long time. Furthermore, the study of diachronic linguistics will be divided into two perspectives, namely prospective and retrospective. A prospective perspective is a perspective with a forward groove, while a retrospective perspective works by means of a flashback or has a backward flow. The researchers applied this Semiotics Theory in this study to see how the social criticism depicted in the lyrics of Hukum Rimba and Buruh Tani.

In this study, the researchers collected data digitally through websites and YouTube platform that supported the study. This study analyzed the implied meanings of several songs belonging to Marjinal band that contain allusions to the government or officials. These are the procedures that the researchers did:

a. Collecting sources from websites focused on Buruh Tani and Hukum Rimba song.

b. Finding out videos of Buruh Tani and Hukum Rimba on YouTube platform. 
c. Analyzing the lyrics by lyrics of the song using the semiotic theory by Ferdinand de Saussure.

\section{RESULTS AND DISCUSSION}

The song of Hukum Rimba and Buruh Tani of this Marjinl band was released in 2016 and in the 2000s. These songs are very popular among workers, students, and the middle to lower class society, because this song really represents the real conditions experienced by the poor. They were extorted by taxes, and faced harsh penalties even though their crimes were nothing compared to corrupt officials. The song called Hukum Rimba has 2 stanzas, and a chorus. Likewise with the farm labor song, it has 2 verses, a chorus and a bridge. Each stanza consists of sixteen lines of songs which are divided into four groups of themes. Within each theme group, it is divided into four lines of songs. The following is a snippet from the lyrics of the jungle law and farm laborers song.

\section{Hukum Rimba - Marjinal \\ Hukum telah dikuasai Oleh orang orang beruang... Hukum adalah permainan Tuk menjaga kekuasaan... \\ Maling - maling kecil dihakimi \\ Maling - maling besar dilindungi \\ Maling - maling kecil dihakimi \\ Maling - maling besar dilindungi}

\section{Buruh Tani - Marjinal}

Buruh, tani, mahasiswa, rakyat miskin kota

Bersatu padu rebut demokrasi

Genggam gempita dalam satu suara

Demi tugas suci yang mulia

Hari-hari esok adalah milik kita

Terciptanya masyarakat sejahtera

Terbentuknya tatanan masyarakat

Indonesia baru tanpa orba

Marilah kawan mari kita kabarkan

Di tangan kita tergenggam arah bangsa

Marilah kawan mari kita nyanyikan

Sebuah lagu tentang pembebasan

Di bawah kuasa tirani

Kususuri garis jalan ini

Berjuta kali turun aksi

Bagiku satu langkah pasti

\section{Analysis of the Hukum Rimba Song Lyrics}

"Hukum Rimba" itself is a song that tells about the practice of law in Indonesia. The title of the song itself is a parable about how Indonesian law is like "Hukum Rimba" where the strong and tough are the ones who are immune to the law while the weak are increasingly being oppressed. In a democratic country like this, the law can be upheld. It doesn't matter if you are rich, poor, an official, the general public or a president, even if you make a mistake in the eyes of the law you must be responsible. But in fact the situation in this country is inversely proportional to the situation we imagine in a democracy. Marjinal band also raised several legal cases in Indonesia which were considered unfair to the lyrics of their songs.

The first verse of the song entitled Hukum Rimba is divided into four parts, each of which consists of four lines of song lyrics. In the first stanza, the first part of the song is:

Hukum adalah lembah hitam

Tak mencerminkan keadilan....

Pengacara juri hakim jaksa

Masih ternilai dengan angka...

The song titled Hukum Rimba begins by taking a parable. The lyrics of the song tell how the laws of this country are like a dark black valley that everyone is afraid of. In this part of the lyrics, it is also told how government officials were blinded by money so as to punish the right and release the wrong. Based on statistical data that we took from the KPK official website. Until 2020 there have been more than 700 cases of corruption, in this case bribery. The KPK also categorizes government officials who have committed these corruption crimes by agency. Most of these officials come from the city government or regional government, provincial government, and ministerial agencies. This proves that the Indonesian legal order is still weak until these officials have the heart to corrupt public money. Marjinal band's want to make people aware that they must move to voice their rights so as not to be constantly oppressed like this.

In the second part, the Marjinal band describes how it is legal in this country. Song as conveyed by Pence, that it is a poem that is conveyed verbally, or in this case sung. In the first lyrics, it is illustrated how the law in this country is more in favor of the bourgeoisie or people who have money. This is like the illustration in the first verse, how government officials who have power and also very 
much money can do everything they can to avoid the law. Just like the title "Law of the Jungle" where he will survive and rule. The second thing discussed in this second part is how officials or rich people use their wealth to remain in power over this country. When they get hit by a criminal case, they will try to cover it up so they don't get caught so they can continue to be in power. The law in this country is like a game. The following are the lyrics of this description:

Hukum telah dikuasai

Oleh orang orang beruang...

Hukum adalah permainan

Tuk menjaga kekuasaan...

Enter the chorus, Marjinal Band used the words "Maling-Maling Kecil", "Maling-Maling Besar" as a description of a person or group. Petty thieves here refer to the general public or the poor who when they commit petty crimes but are severely punished by legal officials. Meanwhile, Big Thief refers to government officials or people who have money. When they commit a very large crime such as corruption, they are even given very little punishment or even acquitted. This proves how Indonesian law is still one-sided. Here are the lyrics in the chorus as follows:

Maling - maling kecil dihakimi

Maling - maling besar dilindungi

Maling - maling kecil dihakimi

Maling - maling besar dilindungi

Hukum adalah komoditas

Barangnya para tersangka...

Ada uang kau kan dimenangkan

Tak ada uang you say good bye...

In this second stanza, the band Marjinal describes the law as a commodity which the suspects use. They also describe how money can handle everything, and if you don't have money then good bye.

Dimanakah adanya keadilan

Bila masih memandang golongan...

Yang kuat selalu berkuasa...

Yang lemah pasti merana...

In this second part, marginal bands question where will justice in this country if the law still views certain groups. According to
W.J.S. Poerwadarminto, the notion of justice is a condition that is not partial or balanced, which should not be decided in an arbitrary manner. In line with the title "Law of the Jungle" where the strong who will rule and the weak will be oppressed, marginal bands use this parable in the lyrics of this second part.

\section{Analysis of the Buruh Tani Song Lyrics}

"Buruh Tani" is the second song that we analyze from Marjinal bands. Similar to Hukum Rimba, this song is also full of very deep meaning. This song tells about the oppression carried out by people who have power in this case are government officials where they oppress the small people who have nothing. This song also has a meaning about how the little people together voice the aspirations of those who have been silenced.

Actually, this song is not originally created by the band Marjinal. They just recomposed and changed a few lyrics and song titles. Quoting from several sources, one of which is online. This song was originally created by Safi'i Kemamang, who was composed when he joined the People's Democratic Party (PRD) in the East Java region, but still operates underground.

When the New Order regime was in full swing, Safi'i and his friends realized that their struggle needed encouragement. Because, according to him, political struggle without music will feel very dry. For that, he thought, one of the instruments to maintain the connecting line of their fighting spirit was poetry and music. Long story short, the song "Liberation" was created in 1996 in Surabaya.

In 1997 in the midst of the repressiveness of the New Order regime, Safi'i, the writer of the song 'Buruh Tani' and his friends, needed encouragement in the political struggle. A song that is thought to be capable of uniting employers, peasants, students, and the urban poor in their fight to reclaim democracy.

Buruh, tani, mahasiswa, rakyat miskin kota

Bersatu padu rebut demokrasi

Genggam gempita dalam satu suara

Demi tugas suci yang mulia

From the statement "Demokrasi genggam gempita dalam satu suara", the author considers the statement to be too grandiose, since a government structure is not a festive party without a single sorrow. This is because any form of government, including democracy, on the face of the planet is bound to have flaws or derogatory ideals. The lyrics of the song tell how we, as a society, must continue 
to struggle to regain democracy and make this a noble task.

Hari-hari esok adalah milik kita

Terciptanya masyarakat sejahtera

Terbentuknya tatanan masyarakat

Indonesia baru tanpa orba

In the second stanza, we can find the lyric, which describes the condition of a classless society was discovered, implying that equal justice for all citizens would be created. This scenario would emerge if "Kita" became the ruler in the sense of the lyrics. The word "Kita" in the song may apply to them as well as those who identify with or consider them. In the second stanza, we can find the lyric, this declaration is describing the condition of a classless society was discovered, implying that equal justice for all citizens would be created. This scenario would emerge if "Kita" became the rulers in the sense of the lyrics. The word "Kita" in the song may apply to them as well as those who identify with or consider them.

Marilah kawan mari kita kabarkan

Di tangan kita tergenggam arah bangsa

Marilah kawan mari kita nyanyikan

Sebuah lagu tentang pembebasan

The statement "marilah kawan, mari kita kabarkan" sulking at the author's desire to unite and invite people to jointly achieve one goal to preach the happy news of the release of the government from the new order regime. Followed by the next sentence "marilah kita nyanyikan sebuah lagu tentang kebebasan" interpreted as society that wants, the form of freedom they call "liberation". A life that is free from various forms of systems or rules that are considered to restrict the existence of society can be felt.

Di bawah kuasa tirani

Kususuri garis jalan ini

Berjuta kali turun aksi

Bagiku satu langkah pasti

The lyrics above illustrated that, even with the circumstances being faced during the New Order regime, the persuasion sentence that invites people to continue to struggle even though is required to take action a million times. The author also wants to believe that together with the community they will be able to overthrow Soeharto's New Order government at that time.

\section{CONCLUSION}

To conclude, the lyrics of the two songs Buruh Tani and Hukum Rimba depicted how people lived in this country. Those who had money could survive and remain in power, while the weak one couldn't do anything. Marjinal band tried to raise the enthusiasm of the people to voice the rights to the officials of this country. At a glance, the lyrics of the song Buruh Tani tried to portray the hopes of workers, farmers, students and the urban poor who wanted a democratic system in Indonesia where they could freely convey their ideas and criticisms without intimidation or even arrest.

\section{REFERENCES}

Ancis. (2011, January 19). Hukum Rimba, Siapa Kuat Dia Yang Menang. Retrieved from Bang Ancis:

https://www.bangancis.web.id/2011/01/huku m-rimba-siapa-kuat-dia-yang-menang.html

Choitim, E. R. (n.d.). Komunitas Anak Punk dan Anomali Sosial. Fakultas Ilmu Sosial dan Ilmu Politik.

Firdaus, E. (2018). Buruh Tani "perjuangan". Retrieved from Steemit: https://steemit.com/dsound/@emirzafirdaus/b uruh-tani-perjuangan.

Gumilang, P. (2017, December 18). Effi Punktat: Indonesia Cocok Untuk Punk. Retrieved from CNN Indonesia: https://www.cnnindonesia.com/nasional/2017 1130230725-75-259405/effi-punktatindonesia-cocok-untuk-punk

Harsinia, D. M. (2009). Teknik Propaganda Dalam Lirik Lagu Marjinal . Propaganda Analisis, 25.

Hornby, A.S. 2000. Oxford Advanced Learner's Dictionary. New York: Oxford University Press.

Hutcheson, F. (1994). 'An Inquiry Concerning Beauty, Order, Harmony, Design.' Philosophical Writings. London: J.M. Dent. 7-44.

Kartika,dewi. 2017. Analisis Semiotika Lirik Lagu Berjudul "Online".

Koentjaraningrat. 2009. Pengantar Ilmu Antropologi. Jakarta: Rinekam Cipta.

Moran, Ian P. (2010) "Punk: The Do-It-Yourself Subculture," Social Sciences Journal: Vol. 10 : Iss. 1, Article 13. 
NK, M. (2018). Komunitas Punk: Sebab,Akibat dan Metode Pembinaan Dalam Prespektif Islam. Jurnal AT-Taujiah Vol 1, 1.

Prayogi, A. k. (2019). Ancis. (2011, January 19). Hukum Rimba, Siapa Kuat Dia Yang Menang. Retrieved from Bang Ancis: https://www.bangancis.web.id/2011/01/huk um-rimba-siapa-kuat-dia-yangmenang.html.

Prinz, Jesse. (2014). The Aesthetics of Punk Rock Philosophy Compass. DOI:

10.1111/phc3.12145
Ramachandran, VS and W. Hirstein. (1999). 'The Science of Art: A Neurological Theory of Aesthetic Experience.' Journal of Consciousness Studies. 6. 15-51.

Setyanto, D. W. (2015). Makna dan Ideologi Punk. ANDHARUPA: Jurnal Desain Komunikasi Visual \& Multimedia, 1(02), 134-141. https://doi.org/10.33633/andharupa.v1i02.964

Wallach, J. (2008). Living the Punk Lifestyle in Jakarta. Ethnomusicology, 52(1), 98-116. Retrieved March 3, 2021, from http://www.jstor.org/stable/20174568 